\title{
"Na estepe", de Samanta Schweblin: um exemplo DE FANTÁSTICO CONTEMPORÂNEO, NA SEQUÊNCIA DO CÂNONE CONSAGRADO POR CORTÁZAR
}

\author{
"On steppe" by Samanta SChWEblin: an example \\ OF CONTEMPORARY FANTASTIC, FOLLOWING \\ THE ESTABLISHED CANON BY CORTÁZAR
}

Flavio Garcia

Universidade do Estado do Rio de Janeiro

Rio de Janeiro, RJ, Brasil

\section{Resumo}

A poética de Samanta Schewblin, no conto "Na estepe", apresenta um esquema mecânico e reiterado no uso de procedimentos próprios dos discursos fantásticos contemporâneos, como, em especial, a falta de informaçóes sobre o objeto que motiva a narração, o que se constitui canônico desde "Casa tomada", de Julio Cortázar. Nesse caso, o emprego do "sujeito tácito" (nome implícito) cria a atmosfera fantástica, inquietante etc., estratégia semelhante a de um nome explicitado, mas do qual o leitor ignora o referente. Esses são procedimentos bastante estudados em relação a Cortázar, que os emprega bastante. A adoção desse recurso por Cortázar justifica as afirmaçóes dos críticos de que Schewblin segue a tradição consagrada por seu ilustre predecessor. É essa a perspectiva a partir da qual se pretende ler "Na estepe", de Samanta Schewblin, entre mundos possíveis da ficção fantástica.

Palavras-chave: novos discursos fantásticos; fantástico contemporâneo; mundos possíveis da ficção; estratégias de construção narrativa; insólito ficcional.

\section{Abstract}

The poetry of Schewblin Samanta, in the story "On steppe", proposed a mechanical and reiterated scheme of fantastic contemporary procedures of the speeches, particularly the nonexistence of information about the motivating object of the narrative, which it was established as canon from "House taken" by Julio Cortazar. In this case, the use of "tacit subject" (default name) creates fantastic, or disturbs atmosphere and so on, similar to the name in an explicit strategy but ignored by the reader. These procedures are fairly analyzed for Cortazar, who frequently uses them. The adoption of this

\section{Resumen}

La poética de Samanta Schewblin, en el relato "En la estepe", propone un esquema mecánico y reiterado en el uso de procedimientos propios de los discursos fantásticos contemporáneos, como la falta de información sobre el objeto que motiva la narración, un procedimiento que se constituyó en canon desde "Casa tomada” de Julio Cortázar. En este caso el uso del "sujeto tácito" (nombre implícito) crea la atmósfera fantástica o desasosegante, estrategia semejante a la de un nombre explicitado, pero del cual el lector ignora el referente. Estos son procedimientos bastante analizados respecto a 
style by Cortázar justifies the position of critics that Schewblin follow her illustrious predecessor, consecrated by tradition. This is the perspective from which it is proposed to read "On steppe" by Samanta Schewblin among other possible worlds of fantastic fiction.

Keywords: new fantastic speeches; contemporary fantastic; possible worlds of fiction; strategies of narrative construction; unusual fiction.
Cortázar, que los utiliza muy a menudo. La adopción de ese estilo por Cortázar justifica las afirmaciones de los críticos de que Schewblin sigue la tradición consagrada por su ilustre predecesor. Es esta perspectiva por la cual se propone leer "En la estepa" de Samanta Schewblin, entre mundos posibles de la ficción fantástica.

Palabras clave: nuevos discursos fantásticos; fantástico contemporáneo; mundos posibles de la ficción; estrategias de construcción narrativa; insólito ficcional.

Samanta Schweblin, em entrevista ao "Caderno G", da Gazeta do Povo, provocada sobre seu percurso ficcional, disse que não sentia muito a presença do fantástico em sua obra e que não se considerava continuadora da literatura fantástica, mas, em ato falho, apontou Casares, Borges e Cortázar como alguns de seus mestres (SCHWEBLIN, 2010). Ainda que a ficcionista negasse pertencer à linhagem de escritores fantásticos, como a crítica acadêmica e jornalística vinha identificando, sua obra publicada atesta o contrário disso. Schweblin agiu semelhantemente a muitos outros autores incontestavelmente fantásticos, que, ao longo do tempo, também se negaram representantes do fantástico, somando a eles.

Ao apontar Casares, Borges e Cortázar como seus mestres, Schweblin admite, ainda que implicitamente, uma gênese literária muito próxima dos novos discursos fantásticos (PRADA OROPEZA, 2006), nos quais adentra pelas sendas do insólito. Ao longo da entrevista, admitiu, ainda, que sua obra é fortemente marcada por inquietaçóes (PABLOS, 2009: E2), provocantes e provocadoras, processo criativo próximo dos mecanismos de construçáo textual que levam à ou se constroem com base na hesitação, traço essencial do fantástico (TODOROV, 2010: 36).

Gustavo Pablos, comentando a obra de Schweblin, em preâmbulos a outra entrevista, destacou que:

un elemento perturbador, inquietante, a veces amenazante - un personaje, un clima, una serie de episodios -, que puede estar casi desde un comienzo, revelarse paulatinamente o bien hacia el final, se termina presentando con una contundencia que pone en suspenso cualquier clase de certeza y de serenidad, y además despliega un poder que transmite la omnipotencia y la arbitrariedad de los hecho (2009: E2). ${ }^{1}$

${ }^{1}$ [...] um elemento perturbador, inquietante, às vezes ameaçador - uma personagem, um clima, uma série de episódios - que pode ser quase desde o início, gradualmente ou revelada no final, 
Admitindo-se que a percepção de Pablos esteja correta, a ficção de Schweblin pode ser considerada seguidora do cânone consagrado por Julio Cortázar, no âmbito do universo do fantástico contemporâneo, espaço discursivo em que "la indeterminación se convierte en un artificio para poner en marcha la imaginación del lector" (ROAS, 2011: 132). ${ }^{2}$

A maioria dos textos que integram seus dois primeiros livros de contos, El nucleo del disturbio (2002) e Pájaros en la boca (2009), envereda pela "brecha entre o fantástico e o real" (FIGUEIREDO, 2012) adentrando os bosques do inquietante e desconfigurando a impressão acolhedora do princípio. Na obviedade da cena quotidiana, irrompe uma voz que redimensiona o mundo, antes ancorado na realidade empírica experienciável pelo leitor mais comum. Com certeza, foi por isso que Pablos inferiu que "su apuesta es por la literatura y por los mundos que desde ella se pueden proponer hacia el mundo" (2009: E2). ${ }^{3}$

Antes da publicação da ediçấo brasileira do segundo livro, cujo título em português corresponde à tradução literal do original em espanhol - Pássaros na boca (2012) -, Schweblin não era conhecida do público leitor e passava despercebida pela crítica no Brasil. Com essa publicação, tanto o leitor mais comum pôde ter acesso à sua obra, quanto a crítica especializada foi alertada sobre sua existência. Schweblin é mais um nome do fantástico contemporâneo que, em 2012, veio à luz no cenário brasileiro.

Para ilustrar a perspectiva adotada neste ensaio, destacar-se-á, de Pássaros na boca, a narrativa "Na estepe" (SCHWEBLIN, 2012: 37-46), na qual se considera que o fantástico "habla a su Lector todo tiempo de la inminencia de un descubrimiento y de lo insatisfactorio del lenguaje para expresarlo" (ARÁN, 1999: 60), ${ }^{4}$ sendo evocado pelo emprego de elementos coesivos, anafóricos ou catafóricos, sem que o referente compareça explicitamente no texto. Essa estratégia que a autora emprega permite comparar sua obra com a de Cortázar, a partir de "Casa tomada" (1986), aproximando a poética desses dois ficcionistas argentinos.

A sensação de inquietude, produto de incertezas das personagens face aos acontecimentos, leva o leitor a também se inquietar diante das ambiguidades que o discurso insólito, seja por sua estruturação linguística - escolhas vocabulares (plano paradigmático) ou construçôes frasais (plano sintagmático) -, seja

\footnotetext{
acaba apresentando-se com uma contundência que coloca em suspense qualquer tipo de segurança e serenidade, e também exibe um poder que transmite a onipotência e a arbitrariedade dos fatos.

${ }^{2}$ [...] a indeterminação se converte em um artifício para pôr em movimento a imaginação do leitor.

${ }^{3}$ [...] sua aposta é pela literatura e pelos mundos que dela se podem propor ao mundo.

${ }^{4}[. .$.$] fala a seu Leitor todo o tempo da iminência de uma descoberta e de que a linguagem é inca-$ paz de expressá-la.
} 
pela ausência ou dubiedade de informaçóes - plano estilístico-pragmático -, provocando, em personagens e leitores, o efeito da hesitação.

Em "Na estepe", a hesitaçáo é conseguida com as incertezas das personagens e as ambiguidades percebidas por elas, contaminando o leitor. Com esse jogo, hesitam, durante todo relato, tanto as personagens, quanto os leitores, e, no fim da história, a hesitação não é resolvida, senão que potencializada por um desfecho em aberto - a narrativa encerra-se in media res. Está-se diante da característica mais importante da narrativa fantástica, segundo defenderam, por exemplo, Todorov (2010) - a hesitação -, Filipe Furtado (1980) - a ambiguidade - e Irène Bessière (1974) - a incerteza -, já que a história termina sem que fossem nomeados os agentes dos eventos insólitos e, nem mesmo explicados os próprios eventos, deixando em suspense sua natureza: empírica ou metaempírica.

$\mathrm{O}$ conto segue uma arquitetura semionarrativa muito semelhante à empregada por Cortázar em "Casa tomada" ${ }^{5}$ Nessas duas histórias, em meio à narração minuciosa de fatos quotidianos, com descrição de espaços e personagens e detalhamento de açóes, irrompem acontecimentos estranhos e inexplicados, atribuídos a seres - a escolha vocabular, em lugar de personagens, é proposital - referidos, mas nunca identificados ou nomeados. Contudo, tem-se certeza de que as personagens sabem, exatamente, do quê e de quem se trata. Nesse aspecto, há um detalhe que distingue a efabulação - ordenação, no plano da diegese, do conjunto de seres, estados, processos e açóes que se apresentam na composição do mundo possível ficcional (ALBALADEJO MAYORDOMO, 1998: 142-149) - das duas histórias. Se, no conto de Cortázar, tem-se a sensação de que as personagens centrais - um homem, o irmão, e uma mulher, sua irmã - sabem o que está acontecendo, porque não se perguntam sobre o que os inominados estâo fazendo, na narrativa de Schweblin, as duas personagens centrais - também um homem, o marido, e uma mulher, sua esposa - não sabem o que "eles", ou "um deles" (SCHWEBLIN, 2012: 38) fazem, perguntando(-se) diversas vezes sobre a efetiva ação acontecida ou sobre sua natureza.

"Na estepe" pode ser visto, dependendo da perspectiva crítica adotada, como um exemplar perfeito e bem acabado do fantástico, pois inquieta as personagens e o leitor, perpetuando a dúvida - hesitaçáo, ambiguidade ou incerteza -, ou como uma narrativa híbrida, que tangencia as fronteiras da ficção científica (FC), uma vez que suscita no leitor a lembrança dos mogwais ou gremlins, personagens de caráter dúbio dos filmes Gremlins (1984) e Gremlins 2: a nova geração (1990), dirigidos por Joe Dante.

Por essas características, não é impróprio sugerir que "Na estepe" perpasse pelos meandros da FC, visto que:

\footnotetext{
${ }^{5} \mathrm{O}$ conto apareceu em 1951 no livro Bestiário, mas originariamente foi publicado em 1946 na revista Anales de Buenos Aires, que dirigia Jorge Luis Borges.
} 
la historia de lo fantástico es una historia marcada por la necesidad de sorprender a un receptor que cada vez conoce mejor este tipo de historias [...], lo que obliga a los escritores a afinar el ingenio para dar con motivos y situaciones insólitos que rompan las expectativas de este. (ROAS, 2011: 93) ${ }^{6}$

Fora isso, "outras tendências contemporâneas [da crítica admitem] [...] a sobreposição da ficção científica, do horror e do fantástico como um meio para reunir novas audiências, novas variedades de literatura de fantasia nacionais ou 'globalizadas'” (GINWAY, 2010: 54). Para Pampa Arán:

El género [fantástico] es una categoría históricamente abierta y de reconocimiento empírico que participa tanto de los cambios en los estilos discursivos cuanto de los cambios sociales. Participa dialógicamente en la obra no como una etiqueta o un modelo fijo, sino gobernando multiplicidad de relaciones de la obra con los códigos de la época, la lengua literaria, los lectores, las instituciones, los sistemas de representación. En este plano, el género forma parte de las políticas o ideologías estéticas de la literatura (y en buena medida también de las políticas del mercado). (ARÁN, 1999: 26)7

Roberto Causo tem ideias muito próximas às de Arán. Para ele, a FC “é ampla o bastante para incorporar características de outros gêneros, sem necessariamente deixar de ser FC" (CAUSO, 2009: 13) e "precisa do leque mais aberto possível de recursos, se deseja evitar a estagnação. A vida humana se desdobra em complexidade, e não espera sentada por nenhum gênero literário" (CAUSO, 2009: 22), enfim:

a FC é um gênero sempre em busca de novas ideias, de novas abordagens. Gabando-se de ser a "literatura da mudança", transita entre a necessidade de expressar criativamente o potencial de transformação da ciência e da tecnologia, e uma objetividade narrativa que, para muitos, é sinal de conservadorismo estético ou da inserção do gênero como puramente comercial. (CAUSO, 2009: 22)

Logo, "misturar gêneros não é novidade dentro do campo da FC" (CAUSO, 2009: 23).

O primeiro parágrafo de "Na estepe" delimita um mundo possível próximo da realidade vivenciável pelo leitor - modelo de mundo possível comprometido com a referencialidade exterior. Seus primeiro e segundo períodos definem o espaço físico, descrevendo como é o cenário; e os terceiro e quarto,

\footnotetext{
${ }^{6}$ A história do fantástico é uma história marcada pela necessidade de surpreender um receptor que cada vez conhece melhor esse tipo de histórias [...], o que obriga aos escritores a afinar o engenho para chegar a motivos e situaçóes insólitos que rompam com as expectativa desse receptor.

${ }^{7} \mathrm{O}$ gênero [fantástico] é uma categoria historicamente aberta e de reconhecimento empírico que participa tanto das mudanças nos estilos discursivos quanto das mudanças sociais. Participa dialogicamente na obra náo como uma etiqueta ou um modelo fixo, senáo que governando a multiplicidade de relaçóes da obra com os códigos da época, da língua literária, dos leitores, das instituiçôes, dos sistemas de representaçáo. Nesse plano, o gênero participa das políticas ou ideologias estéticas da literatura (e em boa parte também das políticas do mercado).
} 
açôes comuns e corriqueiras do dia a dia. Essa estratégia é bastante similar à utilizada por Cortázar em "Casa tomada”, em que os cinco primeiros parágrafos também se referem ao quotidiano esperável e experienciável por qualquer leitor, modelo de mundo cuja verossimilhança aproxima-se da pretensa verdade que se quer ou admite real.

Uma informação surge, no quinto período, prenunciando o enigma que vai se avolumar ao logo da narrativa. A personagem-narrador, que somente mais adiante se saberá chamar Ana, deixa fluir seus pensamentos, revelando que:

quando se está desesperado, quando se chegou ao limite, como nós, então, as soluçôes mais simples, como as velas, os incensos e qualquer conselho de revista parecem opçóes razoáveis. Como existem muitas receitas para a fertilidade, e nem todas tâo confiáveis, aposto nas mais verossímeis e sigo rigorosamente seus métodos. Anoto no caderno qualquer detalhe pertinente, pequenas mudanças em Pol ou em mim. (SCHWEBLIN, 2012: 37)

E o leitor é levado a crer que o casal não tem filhos e os quer ter, mas que enfrenta problemas com a gravidez e busca saídas para resolvê-los. No conto de Cortázar, o enigma não surge assim tão claramente como no de Schweblin, e não são dadas informações muito esclarecedoras sobre a personagem-narrador e sua irmã - Irene. Sabe-se que são solteiros, que ela "recusou dois pretendentes sem motivo maior" (CORTÁZAR, 1998: 11), e que ele viu a namorada Maria Ester morrer sem casar com ela.

O segundo parágrafo, retornando ao processo discursivo empregado anteriormente, informa sobre a rotina de Pol, centrando-se nas suas buscas por soluçôes para o até então presumível problema enfrentado, que parecia ser a falta de fertilidade. Mas o final do parágrafo instaura certo contraponto com a ideia de gravidez, produto da fertilidade, reiterando, todavia, a ideia de espera, associada à gravidez, já que, quando se está grávida, espera-se pelo nascituro. Pol vê-se "revisando atentamente a rotina dos últimos dias para encontrar qualquer detalhe que possa ser corrigido, que nos leve a eles, ou ao menos a um deles: o nosso" (SCHWEBLIN, 2012: 38). Em "Casa tomada", há também um espraiado detalhamento do quotidiano das personagens, mas, nesse ponto, ainda não se deu a irrupção do insólito, que será rápida, subliminar e virá somente em seu quinto parágrafo.

A partir da passagem que encerra o segundo parágrafo de "Na estepe", o leitor náo sabe mais se Ana e Pol buscam meios para que ela fique fértil e engravide, vindo-lhes, consequentemente, um filho, ou se procuram uma forma de serem levados ao encontro de algo enigmático com que esperam se defrontar. Surgem perguntas que serão repetidas ao longo do texto. O que implica "levar a"? Quem são "eles"? Por que um "deles" seria do casal? As dúvidas instauradas, seja quanto ao objeto referido - nunca nomeado ou descrito 
-, seja quanto à sua natureza - empírica ou metaempírica -, permitem localizar a narrativa no universo do fantástico, pois:

producir confianza y despertar sospecha son las instrucciones del texto fantástico dirigidas al Lector. Lo verosímil es siempre una pieza que las estrategias del texto en su conjunto dotan de gran movilidad para tentar al lector a que reconstruya de otro modo el mundo que se creía conocido. (ARÁN, 1999: 58) ${ }^{8}$

No conto de Schweblin, diferentemente de como se dá no de Cortázar, verifica-se uma insistência reiterada de interrogaçóes e interposiçóes de dúvidas, bem como o uso excessivo do pronome pessoal de terceira pessoa, nas formas singular ou plural, ou de seu correspondente possessivo, além dos pronomes indefinidos, sem a explicitação de seu referente. Esse procedimento empresta ao texto um caráter mecânico, distinguindo-o, nesse particular, do conto de Cortázar, no qual, em apenas dois breves momentos, de forma muito sintética, alude-se ao(s) ser(es) inominado(s), uma exemplar sutileza discursiva - em "Casa tomada", a figuração do "sujeito tácito" não se dá pelo emprego de elementos coesivos de referencialidade, como em "Na estepe", em que o recurso a variadas formas pronominais é repetitivo, mas através de construções de sujeito desinencial.

No terceiro parágrafo, adentram-se topoi góticos, onde, "mais adiante o campo se afunda um pouco em longas colinas; avançamos em direção a elas. Nessa zona os arbustos são pequenos, quase conseguem ocultar nossos corpos e Pol acredita que essa é uma das razóes pelas quais o plano fracassa toda noite" (SCHWEBLIN, 2012: 38). Que plano seria esse? A princípio, tudo levava a crer que eles planejassem a fertilidade de Ana, com vista à gravidez, mas, face a essas últimas peripécias, tende-se a duvidar disso, passando-se a crer que se trate de uma caçada. Mas caçada a quê? Nesse mesmo terceiro parágrafo, o enigma é reforçado ainda mais com a informação de que "em várias ocasióes nos pareceu que víamos alguns ao amanhecer" (SCHWEBLIN, 2012: 38). Eles viam "alguns" o quê? De que estão falando, a que se referem? Schweblin exagera no recurso a "la principal estrategia del fantástico [que] consiste en espectaculizar la fragilidad del orden conocido para permitir que lo cotidiano deje de ser indiferente o banal" (ARÁN, 1999: 52). ${ }^{9}$

No quarto parágrafo, novo procedimento discursivo será empregado para reforçar o enigma, com a personagem-narrador assumindo, explicitamente, as dúvidas quanto ao objeto da procura, o que se soma à inquieta-

\footnotetext{
${ }^{8}[$ [...] produzir confiança e despertar suspeita são as instruções do texto fantástico dirigidas ao Leitor. O verossímil é sempre uma peça que as estratégias do texto em seu conjunto dotam de grande mobilidade para seduzir o leitor a reconstruir de outro modo o mundo que acredita conhecido.

${ }^{9}[\ldots .$.$] a principal estratégia do fantástico [que] consiste em espetaculizar a fragilidade da ordem$ conhecida para permitir que o cotidiano deixe de ser indiferente ou banal.
} 
ção já experimentada pelo leitor. Ana, semelhantemente ao que já fizera no primeiro parágrafo, deixa fluir seus pensamentos, contando que "sempre me perguntei como serão realmente" (SCHWEBLIN, 2012: 38), e confidencia: "Creio que são iguais aos da cidade, só que mais rústicos, talvez mais selvagens" (SCHWEBLIN, 2012: 38). O emprego do fluxo de consciência "método narrativo relacionado com momentos significativos de introspecção, que se podem combinar, em muitos casos, com monólogos interiores" (TAVARES) - é um processo igualmente utilizado nos contos de Cortázar e Schweblin. Tanto a descrição minuciosa de personagens, espaços e tempos, quanto o detalhamento das açóes narradas, bem como as impressóes subjetivas da personagem-narrador acerca desses elementos, são estratégias que participam, nos dois contos, com a função de estruturar o texto. Assim, a apreensão da realidade textual se dá através da focalização - "modo [...] de regulação da informação na ficção" (RITA) - exclusiva do sujeito narrador, no caso do conto de Cortázar, o irmão de Irene, no de Schweblin, Ana, a mulher de Pol.

Adiante, nesse mesmo parágrafo, a comparação que Ana sugere entre "os da estepe", mais rústicos, mais selvagens, e "os da cidade", iguais no restante, acrescenta um toque de mistério ao enigma. O que um casal, que parecia querer gravidez, envidando esforços pela fertilidade, busca na estepe - ambiente rústico, selvagem -, sendo esse elemento - ser inominado, inidentificado, que náo se sabe ser de natureza física ou metafísica - igual ao que houvesse na cidade, observando, apenas, a distinção provável entre um ser rústico e selvagem e a suposiçâo de "o outro" ser civilizado e educado?

Retorne-se, pois, à questão inicialmente colocada neste ensaio, já que, embora a escritora argentina negue sua veia fantástica, ela recorre, com percuciência, a:

las propiedades estructurantes del mundo posible del fantástico, según el canon de las convenciones genéricas. Es un mundo minuciosamente semejante al mundo real en el que "algunos" individuos, seres o cosas, exhiben propiedades diferentes de las que le son pertinentes en el mundo de referencia, sin dejar de mantener su semejanza. El escándalo racional se produce, precisamente porque las propiedades pertinentes y no pertinentes coexisten en un mismo individuo o en el medio que le rodea, sin que sea posible explicar el origen o la causa del desorden natural y sin que tampoco sea posible verificar su duración o alguna de las regularidades de su comportamiento. (ARÁN, 1999: 43-44) ${ }^{10}$

\footnotetext{
${ }^{10}[\ldots]$ as propriedades estruturantes do mundo possível do fantástico, segundo o cânone das convençôes genéricas. É um mundo minuciosamente semelhante ao mundo real em que "alguns" indivíduos, seres ou coisas, exibem propriedades diferentes das que lhe sáo pertinentes no mundo de referência, sem deixar de manter sua semelhança. $O$ escândalo racional se produz, precisamente porque as propriedades pertencentes e não pertencentes coexistem em um mesmo indivíduo ou no meio que o rodeia, sem que seja possível explicar a origem ou a causa da desordem natural e sem que tampouco seja possível verificar sua duraçáo ou alguma das regularidades de seu comportamento.
} 
Na edição brasileira de "Na estepe", há um maior afastamento - separação física - entre o quarto e o quinto parágrafos, o que parece sugerir uma ruptura na sequência narrativa, delimitando uma mudança de plano diegético, como em passagens de teatro, cinema ou tevê. Recurso semelhante também se verifica na edição brasileira de "Casa tomada", entre os mesmos quarto e quinto parágrafos. No conto de Cortázar, essa estratégia se repete entre o quinto e o sexto parágrafos, no qual se dá a primeira manifestação do insólito, em que a personagem-narrador ouve barulhos estranhos em alguns cômodos localizados em um dos lados da casa e, sem maiores explicaçóes, atira-se "contra a porta antes que fosse demasiado tarde", fechando-a "violentamente" com a chave e, "além disso", passa-lhe "o grande ferrolho para maior segurança", porque, conclui, "tomaram a parte dos fundos" (CORTÁZAR, 1998: 14), e torna a incidir entre outros parágrafos sucessivos, agrupados em blocos que, nesse caso, delimitam, além da mudança de núcleo acional, passagens de tempo.

Ao amanhecer, Ana e Pol voltaram da floresta sem, mais uma vez, terem encontrado o que procuravam, e, enquanto Pol foi à cidade, Ana ficou sozinha em casa. Em "Casa tomada", Irene também fica só, em casa, quando seu irmão ia à cidade, alongando-se, fora, na procura por novos livros franceses (CORTÁZAR, 1998: 12). No texto de Schweblin, retomam-se nesse ponto estratégias narrativas já utilizadas, com o relato de ações que são apontadas como habituais, corriqueiras na vida do casal. A personagem-narrador diz que:

Agora estou sozinha em casa, olhando a entrada da cozinha. Esta manhã, como sempre, nos levantamos tarde e almoçamos. Depois Pol foi ao povoado com a lista de compras e os artigos para revista. Mas já é tarde e faz tempo que ele devia ter voltado, e ainda não apareceu. Então vejo a caminhonete. Ao chegar em casa me faz sinais pelo para-brisa para que saia. Eu o ajudo com as coisas. Ele me cumprimenta (SCHWEBLIN, 2012: 39).

O quarto período desse último parágrafo, que se inicia pela conjunção adversativa "mas", introduz uma fratura na sequência de regularidades, afinal, a demora na volta de Pol não era acontecimento previsível - já no conto de Cortázar, destaca-se como sendo fato comum o irmão de Irene deixar-se ficar na cidade em busca de novidades da literatura francesa. À frente, contudo, a partir do que Pol dirá a Ana, a narrativa se encaminhará de modo especialmente significativo. Ele chega de volta à casa com a novidade de que, na visita ao povoado, conhecera um casal que também estava na estepe pelo mesmo motivo que eles, e "já têm um deles, já vai fazer um mês". ${ }^{11}$ Novamente, em meio à normalidade aparente, reacende o enigma: o que seria "um deles"? Ana não se contém: “- Eles têm um? Têm um! Não posso acreditar...” (SCHWEBLIN, 2012: 39).

\footnotetext{
${ }^{11}$ Os trechos citados sem indicação imediata estão compreendidos na citação subsequente no mesmo parágrafo.
} 
Pol conta-lhe que o casal os convidou para jantar naquela mesma noite e ela fica eufórica, alegra-se. A cada revelação que ele lhe faz, ela demonstra maior inquietaçấo. Revela sentir inveja, seja pelo que Pol já sabe do casal - ainda que nada saiba do tal ser inominado que desejam -, seja pelo casal já ter conseguido "um deles". E Ana pergunta-lhe "como é?", se o "chegou a ver?". Mas Pol diz-lhe que não, eles o deixaram em casa - Pol nada sabe do ser, salvo que o casal já tem o seu, já o conseguiu. Ana não consegue entender como podem tê-lo deixado em casa sozinho, e inquire: "- Como assim, deixam em casa? Sozinho?”. Pol não sabe o que lhe responder, e ela não entende a falta de curiosidade dele, deixando fluir que "assim mesmo peço mais detalhes enquanto prossigo com os preparativos" (SCHWEBLIN, 2012: 40). Que preparativos seriam esses e para quê, se apenas iriam a um jantar? Mas vão ao encontro do casal afortunado, que já tem "um deles", como também querem ter.

Ana revela que "fechamos a casa como se não fôssemos voltar durante muito tempo. Colocamos agasalhos e saímos [rumo ao jantar]" (SCHWEBLIN, 2012: 40). Reincidentemente, outra espécie de incoerência desponta, pois a informaçáo sobre o fechamento da casa - relação entre a maneira como se a teria fechado e o tempo correspondente aos cuidados empregados nessa maneira - não condiz com a ocasiáo de ida à casa de alguém para um jantar, ainda que esse jantar estivesse imerso em uma aura feérica, devido ao enigma e ao desejo ainda inalcançado que o envolviam.

Durante o trajeto da ida, Ana pensa nas conversas que poderá ter com Nabel, mulher de Arnol, nas perguntas que lhe fará, "quando Pol convide Arnol a um charuto [e] nos deixem a sós". Chega a crer que "talvez então possa falar com ela sobre coisas mais privadas, talvez Nabel também tenha usado velas e sonhado com coisas férteis de vez em quando e agora que conseguiram possam nos dizer exatamente o que fazer" (SCHWEBLIN, 2012: 40). Esse trecho, retomando aspectos presentes em passagens anteriores do texto, reacende a questão da fertilidade, consequentemente, da gravidez, coligando o fato de Nabel e Arnol terem "um deles" ao nascimento, pois, em nossas culturas neolatinas, é tradição um homem oferecer charuto a outro, quando este se torna pai.

Arnol e Nabel são figurados - o conceito de figuração designa um processo ou um conjunto de processos constitutivos de entidades ficcionais, de natureza e de ação antropomórfica, conduzindo à individualização de personagens e universos específicos, com os quais essas personagens interagem (REIS, 2014: 52) -, ao longo do parágrafo a seguir - dimensionalmente desproporcional em relação aos demais -, em consonância com os protocolos ficcionais próprios do sistema semionarrativo literário real-naturalista, destacando-se aspectos comuns de sua caracterização. 
A partir de comparações feitas por Ana e que seus pensamentos deixam fluir - o recurso ao fluxo de consciência da personagem-narrador é a mais utilizada em "Casa tomada" -, os dois casais são postos no plano da normalidade, da naturalidade, da realidade esperável. Em meio a isso, irrompe uma pergunta feita por Ana, que quer saber "como o agarraram, como é, como se chama, se come bem, se já foi examinado por um médico, se é tão bonito como os da cidade" (SCHWEBLIN, 2012: 41). Logo, se foi agarrado, não fertilizado, gestado e parido, encontra-se fragilizada a outra versão que parecia ser possível. Querer saber se come bem e se foi examinado por um médico não exclui nem a possibilidade de se estar referindo a um ser humano, um animal ou a um ser alienígena, pois os veterinários também são médicos e, conforme é próprio da FC, os alienígenas acabam, via de regra, examinados por médicos ou cientistas. Contudo, Ana não sabe como "ele" é e, em seus discurso, toma por referência comparativa "os" da cidade, que faz parecer que conhece - mas que, também, não nomeia nem caracteriza distintivamente, pois, como se acaba percebendo, não conhece, de fato, o ser por ela desejado. Em suas comparações, ela destaca, apenas, a presunção - é-se levado a crer que não passe de presunção - de "os" da cidades serem bonitos. A dúvida sobre a natureza desses seres, que inquieta Ana, é reiterada e amplificada desse momento em diante.

Nabel não responde prontamente às perguntas de Ana, e "a conversa [entre elas], porém, alonga-se em assuntos vagos", recompondo o clima sombrio do início do parágrafo. Até que Ana não se contém em sua inquietude e volta a perguntar: "- É lindo?". Nabel apenas "enrubesce e sorri”, e, em novo fluxo de consciência, Ana pensa: "eles têm um", "têm um e é bonito" (SCHWEBLIN, 2012: 41). A falta de respostas intensifica as dúvidas, inquietando ainda mais Ana e, por contaminação, o leitor também se inquieta trata-se de uma estratégia narrativa própria do relato fantástico: levar a que leitor, juntamente com as personagens e, em geral, com o próprio narrador, cuja funçáo costuma ser desempenhada de modo auto ou homodiegético (narrador-protagonista ou narrador-deutaragonista), experiencie a hesitação, as ambiguidades, as incertezas, e fique inquieto frente às dúvidas que a narrativa representa discursivamente.

Incontida, Ana declara: “- Quero vê-lo”. Inquieta, pensa "Quero vê-lo já", imagina que Nabel lhe atenda, "diga 'por aqui”", e "finalmente poderei vê-lo, pegá-lo no colo" (SCHWEBLIN, 2012: 42). Pensar em "pegá-lo no colo" reacende as dúvidas, pois tanto se pega um bebê no colo, quanto um animal, e, no filme Gremlins, os bonitos e amáveis monstrinhos, que, inesperadamente, se tornam diabólicos e destruidores, são, igualmente, acariciados e postos no colo por seus possuidores. Rosalba Campra detectou que "en 
la literatura fantástica contemporánea [...] a menudo el evento fantástico no actúa como un elemento de cierre [...], sino más bien como un detonador que abre otras posibilidades: que exige otras lecturas" (CAMPRA, 2008: 61) ${ }^{12}$ e é, dessa maneira, que se dá no texto de Schweblin.

Ao longo dos parágrafos seguintes - entremeados de diálogos, mas, também, repletos de fluxos de consciência da personagem-narrador -, têm-se as investidas de Ana e Pol, na tentativa de verem o ser desejado, que Nabel e Arnol guardam recluso no quarto, e os recursos de postergação, que estes empregam para impedir o acesso daqueles. "-Ana está ansiosa para conhecê-lo - diz Pol". Ainda assim, "Arnol ri, mas, em vez de responder, póe a travessa na mesa e pergunta quem gosta de carne mal passada e quem de mais cozida" (SCHWEBLIN, 2012: 42). Ainda outra vez, conversam e descobrem terem vidas parecidas.

Ana irrompe, novamente, com mais perguntas: “- $\mathrm{E}$ as saídas? As caçadas noturnas? [...] As mochilas?” (SCHWEBLIN, 2012: 42). Retorna aqui a oposição, mesmo na distância, entre fertilidade e gravidez, e caçada e captura. São feitas, por Ana e Nabel, referências às saídas noturnas, à necessidade de lanternas, ao uso de redes - que parecem ser redes de caça. Nabel fala de escopeta e de tiros - o que, novamente, remete à ideia de caçada -, que teriam atrapalhado a captura - captura encontra-se no campo semântico de caçada - do ser que agora têm sob guarda, no quarto da casa. Diz ela: “- E a escopeta [...]. Pelo amor de Deus, Arnol! Se você parasse de atirar! Nós o teríamos encontrado muito mais rápido" (SCHWEBLIN, 2012: 43). Mas nem Nabel, nem Arnol deixam entrever a intenção de permitir que vejam o ser.

Frente a cada pergunta de Ana ou Pol, póem-se-lhes uma resposta dissimuladora, postergando o encontro. "Já vão vê-lo - diz Arnol", "Dorme demais - diz Nabel”, "O dia inteiro", parecem dizer os dois. Ana e Pol não se importam de o ver dormindo. "Então o vemos dormindo - diz Pol", "gostaríamos de vê-lo adormecido", insiste. Mas Arnol corta com um seco "Não [...] - Digo: não faz nenhum sentido vê-lo assim. Para isso, podem vê-lo outro dia qualquer" (SCHWEBLIN, 2012: 43). O que é "ele"? Não se disse ainda - e nem se dirá. Em mais esse protocolo, o texto de Schweblin marca-se nos limites da literatura fantástica, uma vez que "lo fantástico es la única categoría literaria (estética) que no puede funcionar sin la presencia de lo imposible" (ROAS, 2011: 46). ${ }^{13}$

Ana e Pol tentam, a todo custo, driblar os diferentes obstáculos interpostos ao seu intento, porém, Nabel e Arnol fecham-se no bloqueio às inves-

\footnotetext{
${ }^{12}[\ldots]$ na literatura fantástica contemporânea [...] frequentemente o evento fantástico não atua como um elemento de finalizaçáo [...], mas como um detonador que abre outras possibilidades; que exige outras leituras.

${ }^{13}[\ldots]$ o fantástico é a única categoria literária (estética) que não pode funcionar sem a presença do impossível.
} 
tidas. Serve-se o jantar, oferece-se repetição de pratos; propõe-se jogar - de fato, o que ali se dá, no plano narrativo, é um jogo: de palavras, de estratagemas, de simulaçôes e dissimulaçôes (fingere). Tudo são disfarces para, como uma estratégia refletida no plano da diegese, produzir tanto a inquietação nas personagens Ana e Pol, quanto comunicá-la ao leitor, já que uns e outro nada sabem desse ser inominado - "sujeito tácito", aquele que nunca é nomeado explicitamente no discurso narrativo, ainda que se saiba de sua existência. Resta a Ana e Pol - como, de modo similar, ao leitor - furar o bloqueio e encontrar respostas para as dúvidas interpostas: o que é, como é esse ser inominado, indescritível, elíptico, de materialidade ausente, mas presente nos vazios do discurso, pela referencialidade das açôes e adjetivaçôes, e no desejo de Ana e Pol e na suposta posse de Naber e Arnol?

Nabel e Ana vão para a cozinha, deixando os homens na sala. Uma se ocupa do café, outra da sobremesa, e as duas se entretêm. Pol pergunta a Arnol sobre o banheiro, que, procurando Nabel com os olhos, balbucia "que não funciona bem e...”. Pol torna a querer saber "onde fica?". Nesse momento, "talvez sem querer, Arnol olha para o corredor. Então Pol se levanta e começa a caminhar". Sem conseguir detê-lo, Arnol adverte que "o banheiro é o da direita”. A tensão narrativa chega às portas do clímax. Ana volta à sala e procura entreter Arnol, dando cobertura a Pol, que, ela já sabe, pretende ir ao quarto ver o ser. Ana fala, Arnol não responde. Nabel está prestes a retornar com o café. Ana vê "Pol sair silenciosamente do banheiro e cruzar o corredor para o outro cômodo". Mais tensão, adentra-se no clímax narrativo. "A luz do quarto se acende [...] um ruído surdo, como algo pesado sobre um tapete". Ainda mais tensão: "Arnol está em via de se virar para o corredor" (SCHWEBLIN, 2012: 44). Ana o chama, tenta manter-lhe voltado para si, garantindo tempo para Pol agir.

A tensão atinge seu ápice, e o clímax eclode: "outro ruído [...]; Pol grita e algo cai no chão, $[. .$.$] coisas [. .$.$] se quebram”. O que houve no quarto? \mathrm{O}$ trágico se anuncia: "Arnol corre até corredor e pega o rifle", mas para atirar em quem, em quê? "Pol sai do quarto de costas, sem deixar de olhar para dentro", e o que vê? Ana não consegue "entender o que está acontecendo". Ela e Pol saem da casa, a porta se fecha lentamente atrás deles, depois, volta a abrir-se, e surge a dúvida se seria Arnol que vinha para atirar neles. "Pol sobe na caminhonete e dá a partida" (SCHWEBLIN, 2012: 45). Ana sobe pelo seu lado. Saem de marcha a ré, apressados, apavorados.

Não se pode dizer que, no conto de Cortázar, haja, como é evidente no de Schweblin, um processo intenso de inquietaçôes, do início da história até a primeira manifestação do insólito, quando se dá a saber da existência de seres inominados e indescritíveis, momento em que eles "tomaram a parte dos fundos 
[da casa]" (CORTÁZAR, 1998: 14). Nem se pode, mesmo, apontar qualquer efervescência desde esse ponto até a segunda e única referência direta àqueles seres, quando eles "tomaram esta parte [da casa]" (CORTÁZAR, 1998: 17), na qual Irene e seu irmão se mantinham resguardados. O clímax, contudo, prenunciando o desfecho - in media res - instaura-se nesse momento em que o casal de irmãos se sente ameaçado, ao que parece, em sua integridade física. Não lhes resta outra saída - como parece ter-se dado a Ana e Pol, no conto de Schweblin - a não ser evadirem-se, porque, como sintetiza a personagem-narrador, "agora é tarde" (CORTÁZAR, 1998: 17). Eles saem à rua, com o quase nada que tinham consigo no momento da fuga imediata, deixando todo o resto para trás.

No desfecho da história de Schweblin, Ana ainda vai contar que:

já na estrada andamos um tempo em silêncio, tratando de nos acalmar. Pol tem a camisa rasgada, quase perdeu por completo a manga direita e no braço sangram uns arranhôes profundos. [...] ele respira agitado, as mãos tensas agarradas ao volante. (SCHWEBLIN, 2012: 45)

O que Pol teria visto no quarto? O que aconteceu lá dentro? Por que Pol gritou? Quem ou o que arranhou táo profundamente o seu braço? Ele dirige em alta velocidade, Ana tenta detê-lo, calculando que pudessem se matar, "caso um animal cruzasse o caminho", todavia, seu esforço é em vão. Ainda cogita: "[...] penso que também se poderia cruzar com um deles: o nosso". Seria um animal?, recoloca-se a questáo. E "Pol acelera ainda mais, como se de dentro do terror de seus olhos perdidos contasse com essa possibilidade" (SCHWEBLIN, 2012: 46). Ele está aterrorizado. Fogem!

$\mathrm{Na}$ exasperada saída de Ana e Pol, as falas e o fluxo de consciência de Ana ressoam uma tristeza, um descontentamento, uma frustração pelo desfecho mal sucedido. Situação semelhante se dá em "Casa tomada", com a personagem-narrador - na mesma posição e função que Ana - dizendo que "antes de nos afastarmos senti tristeza, fechei bem a porta de entrada e joguei a chave no bueiro. Náo fosse algum pobre-diabo resolver roubar e entrasse na casa, a essa hora com a casa tomada" (CORTÁZAR, 1998: 18). Ana e Pol não conseguem possuir um daqueles seres que desejam, findando sua história em aberto. Irene e seu irmão náo conseguem manter a casa de que gostavam, "porque, além de espaçosa e antiga [...], guardava as recordaçóes [- como exprime, em fluxo de consciência -] de nossos bisavós, o avô paterno, nossos pais e toda a infância" (CORTÁZAR, 1998: 11). A casa ganha, na voz da personagem-narrador, estatuto de personagem, pois, como afirma, "é da casa, porém, que me interessava falar" (CORTÁZAR, 1998: 11). Todo o quinto parágrafo do conto, que antecede à primeira manifestação do insólito, com a descoberta e denúncia da presença dos seres inominados na parte dos fundos da casa, é dedicado à sua figuração - termo de que aqui se pode apropriar, seja pela "personificaçáo" que essa 
categoria adquire no relato, seja pelo fato de poder inferir, a partir de Gérard Genette (2004), que a composição ficcional de personagem, espaço e tempo (as três categorias essenciais de qualquer narrativa) residem nas bases do conceito de figura.

Ficam perpetuadas, para além do desfecho dessas duas histórias - na de Cortázar, menos intensiva e mecanicamente, ao contrário do que se verifica na de Schweblin, que tangencia o exagero da mecanicidade no emprego de algumas estratégias -, várias questóes que, ao longo da narrativa, foram sendo levantadas - umas reiteradas, outras abandonadas, mas nenhuma delas respondida. A despeito das diferenças no recurso e emprego das estratégias de construção narrativas próprias à composição dos mundos possíveis ficcionais do fantástico, "Casa tomada" e "Na estepe" são textos que apresentam, em seu construto, protocolos essenciais da literatura fantástica.

"Na estepe", queira sua autora admitir ou não, é uma narrativa que se pode inscrever no cânone celebrizado por Julio Cortázar, representando um exemplar dos novos discursos fantásticos, nas expressóes latino-americanas do fantástico contemporâneo.

\section{Referências bibliográficas}

ALBALADEJO MAYORDOMO, Tomás. Teoría de los mundos posibles y macroestructura narrativa. Alicante: Publicación de la Universidad de Alicante, 1998.

ARÁN, Pampa Olga. El fantástico literario. Aportes teóricos. Madrid: Tauro, 1999.

BESSIÈRE, Irène. Le récit fantástique. La poétique de l'incertain. Paris: Larousse, 1974.

CAMPRA, Rosalba Territorios de la ficción. Salamanca: Renascimiento, 2008.

CAUSO, Roberto de Sousa. "Introdução: intersecções na ficção científica brasileira”.

In: (Ed.). Os melhores contos brasileiros de ficçâo cientifica: fronteiras. São Paulo: Devir, 2009. p. 11-24.

CORTÁZAR, Julio. “Casa tomada”. In: Bestiário. Rio de Janeiro: Nova Fronteira, 1986. p. 11-18.

FIGUEIREDO, Janaína. "Samanta Schweblin e a estranheza ao que parece banal". O Globo. Prosa, Cultura. Disponível em: <http://oglobo.globo.com/blogs/ prosa/posts/2012/04/14/samanta-schweblin-a-estranheza-ao-que-parecebanal-440219.asp>. Acesso em: 25 jun 2014 (2012).

FURTADO, Filipe. A construção do fantástico na narrativa. Lisboa: Horizonte, 1980.

GENETTE, Gérard. Metalepsis. De la figura a La ficción. Buenos Aires: Fondo de Cultura Económica, 2004.

GINWAY, M. Elizabeth. Visão alienígena: ensaios sobre ficção científica brasileira. São Paulo: Devir, 2010.

PABLOS, Gustavo. “'Algo tiene que ser perturbador para que me siente a escribir'. Entrevista a Samanta Schweblin, escritora”. La Voz Del Interior. Cultura, p. E2. Disponível em: <http://archivo.lavoz.com.ar/anexos/Informe/09/7813.pdf>. Acesso em: 23 jun 2014 (2009). 
PRADA OROPEZA, Renato. "El discurso fantástico contemporáneo: tensión semántica y efecto estético”. Revista Semiosis. Tercera Época. Xalapa, Veracruz, México: Instituto de Investigaciones Lingüístico-Literarias. v.2, n.3, p. 54-76, 2006.

REIS, Carlos. "Pessoas de livro: figuração e sobrevida da personagem". Revista de Estudos Literários - Personagem e Figuração. Coimbra: Centro de Literatura Portuguesa da Universiade de Coimbra. n.4, p. 43-68, 2014.

RITA, Annabela. "Focalização". In: CEIA, Carlos (Org.). E-Dicionário de Termos Literários (EDTL). Disponível em: <http://www.edtl.com.pt/businessdirectory/6376/stream-of-consciousness/>. Acesso em: 1 set 2015.

ROAS, David. Tras los límites de lo real: una definición de lo fantástico. Madrid: Páginas de Espuma, 2011.

SCHWEBLIN, Samanta. "Na estepe". In: - Pássaros na boca. Sáo Paulo: Saraiva, 2012. p. 37-46.

. "A dama da nova literatura argentina Samanta Schweblin, escritora". Gazeta do Povo. Disponível em: <http://www.gazetadopovo.com.br/cadernog/ conteudo.phtml?id=1010613>. Acesso em: 23 jun 2014.

TAVARES, Vera. "Stream of consciousness". In: CEIA, Carlos (Org.). E-Dicionário de Termos Literários (EDTL). Disponível em: <http://www.edtl.com.pt/businessdirectory/6376/stream-of-consciousness/>. Acesso em: 1 set 2015.

TODOROV, Tzvetan. Introdução à literatura fantástica. 4.ed. São Paulo: Perspectiva, 2010.

Flavio García é professor associado da Universidade do Estado do Rio de Janeiro, pós-doutor pela UFRJ, UFRGS e UC (Portugal); autor de Novos discursos fantásticos de Mia Couto (Dialogarts, 2013) e organizador de Vertentes do fantástico no Brasil (Dialogarts, 2015), (Re)Visóes do Fantástico (Dialogarts, 2014), As arquiteturas do medo e o insólito ficcional (Caetés, 2013), Murilo Rubião 20 anos depois de sua morte (EdUERJ, 2013) e Vertentes teóricas e ficcionais do insólito (Caetés, 2012).

E-mail: flavgarc@gmail.com. 